\title{
植皮裏装を行った腹直筋皮弁による㚘部再建例
}

\author{
演口裕弘·古郷 幹彦·白砂兼 光* \\ 小倉孝文・向井紀文・松矢篤三

\section{Reconstruction after buccal cancer surgery using a skin-grafted rectus abdominis flap} \\ Munehiro Hamaguchi $\cdot$ Mikihiko Kogo $\cdot$ Kanemitsu Shirasuna* \\ Takafumi Ogura $\cdot$ Norifumi Mukal $\cdot$ Tokuzo Matsuya
}

\begin{abstract}
We described our experience with a recurrent case of buccal cancer in which reconstruction was performed with a skin-grafted rectus abdominis flap. The patient was a 61 year-old woman. She had been undergone tumor excision and reconstruction with a D-P flap at 54 years of age (histopathological diagnosis, acinic cell carcinoma). Recurrence occurred 7 years later. We planned to excise the tumor and perform reconstruction with a rectus abdominis flap. A rectus abdominis flap was prepared before tumor excision, at the same time, free skin was grafted to the raw surface of the flap. Three weeks later, the tumor was excised, and reconstruction was performed. The rectus abdominis flap covered with skin was positioned so that the skin side of the flap formed the cheek and the graft side formed the oral wall. Fat reduction of the flap was performed 18 days later. The flap was successfully transplanted without any necrosis. The outcome was excellent because the flap resembled the natural curve of the cheek. This method is useful for secondary reconstruction and for reconstruction after excision of benign tumors or slowly progressing cancers, such as salivary grand carcinomas.
\end{abstract}

Key words: buccal cancer (煩部癌), reconstruction (再建), rectus abdominis flap (腹直筋皮弁)， skin graft（遊離植皮）

緒言

再建手技の発展は口腔癌に対する外科的切除範囲の 拡大を可能とし治癒率の向上に貢献している。しかし ながら口腔癌再発例においては切除範囲が大きく，そ の上，有効な皮弁はすでに一次治療時に使用している

大阪大学歯学部口腔外科学第一講座

(主任：松矢篤三教授)

The First Department of Oral and Maxillofacial

Surgery, Osaka University Faculty of Dentistry

(Chief: Prof. Tokuzo Matsuya)

-九州大学菌学部口腔外科学第二講座

(主任：白砂兼光教授)

- The Second Department of Oral and Maxillofacial Surgery, Kyusyu University Faculty of Dentistry (Chief: Prof. Kanemitsu Shirasuna)

受付日: 平成 8 年 1 月 29 日
ため，再建法の選択に苦労することがある ${ }^{11}$ ，近年マ イクロサージェリーの目覚ましい進歩により, 種々の 組織欠損に対して遠隔の部位から大きな組織を移植す ることが可能になってきている2．

今回われわれは, 煩粘膜癌再発例に対し, 植皮婁装 を行った腹直筋皮弁で再建を行い，良好な成積を得た ので報告する。

症
患 者: 61 歳 女性.
初 診 : 昭和 58 年 9 月
主 訴 : 右側煩部の腫脹.
既往歴 : 糖尿病にてダオニール $\mathrm{R} 1 \mathrm{~T} / \mathrm{day}$ 服用.
家族歴 : 特記事項なし.
現病歴 : 昭和 57 年 1 月右側煩部の腫脹に気づくも




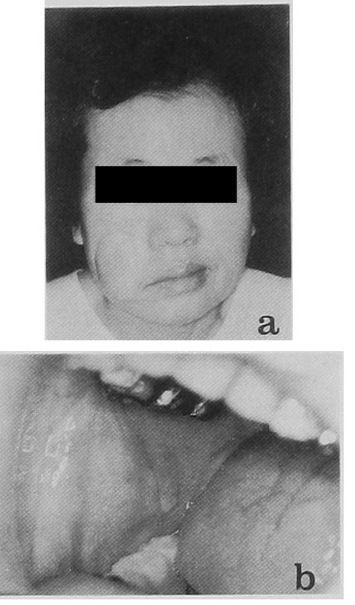

写真 1 術前写真 ( $a$ : 顔貌, b: 口腔内)
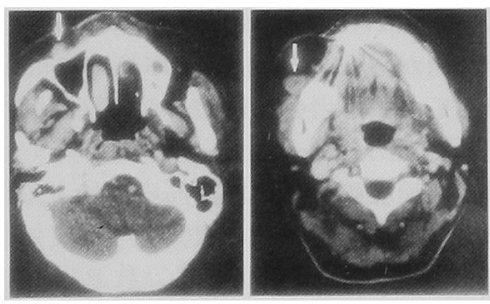

写真 2 CT 写真

2 箇所に tumor mass 認めた (知印).

放置していたところ徐々に増大傾向を示したために昭 和 58 年 9 月—本院にて初診の後, 腫湯切除術を受 けた (病理組織: 腺房細胞腫). 原発部の再発と顎下リ ンパ節への転移を認めたため昭和 62 年 7 月に㚘部腫 䛲切除術，右側上頸部郭清術，D-P 皮弁移植術を受け た.な㧍病理組織は初診時と同様であった ${ }^{3)}$. 術後経 過は良好で, 以後外来にて経過観察を行っていた，平 成 6 年 7 月当科再診時に D-P 皮弁移植部に腫瘤を触 知したため, 精查を行った。

現 症:

全身所見：身長 $150 \mathrm{~cm}$ ，体重 $47 \mathrm{~kg}$.

口腔外所見：煩部皮唐表面は正常であったが，D-P 皮弁と煩骨接合部に直径 $1.5 \mathrm{~cm}$ の腫瘤を触知した.さ らにD-P 皮弁と盿筋付着部に直径 $1 \mathrm{~cm}$ の腫瘤を触知 した. 腫瘤は共に疼痛や発赤もなく圧痛などの所見も 認めなかった。

口腔内所見 : 煩粘膜表面は正常で腫脹も認めなかっ た(写真 1$)$.

CT 所見：上顎骨と D-P 皮弁に接するように境界明 瞭で均一な類円形の領域を認めた。また下顎部でも皮 弁と骨の間に境界明瞭で均一な類円形の領域を認めた (写真 2). 同部の生検より病理組織は腺房細胞腫で

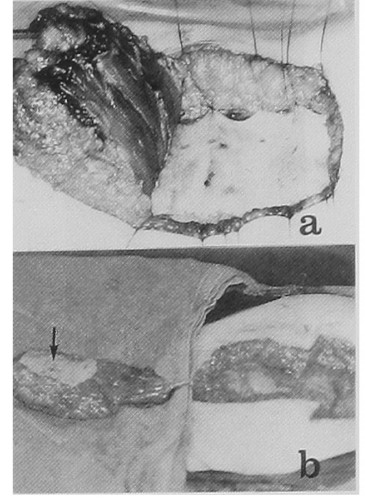

写真 3

(a) delay 処置 : 挙上された腹直筋皮并の下面に全層皮 唐を縫合固定している

（b）腹直筋皮弁の挙上: 筋皮并の内面に皮署が生着して いる (矢印).

あった。

処置および経過：本症例に対して腫瘍切除術と腹直 筋皮弁による煩部再建術を施行した．臨床所見ならび にCT 所見などより腫瘍の切除範囲を決定し， $9 \times 6$ $\mathrm{cm}$ の腹直筋皮弁をデザインした，腫淿切除に先立っ て9月—全身麻醉下に腹直筋皮弁の皮弁作製術を 行った. 皮弁作製に際しては再建後の口腔側の raw surface を被覆する目的で，挙上した腹直筋皮弁の亭 面に遊離植皮を行った（写真 $3 \mathrm{a} ）$.大腿部より探取し た全層皮膚を腹直筋後鞘に縫合固定し内面が腹直筋の 筋腹に確実に接するようにし，さらに上部をガーゼで タイオーバー固定した。

皮弁作製術 3 週間後に全身麻酔下にて腫啺切除を行っ た. 腫場切除は D-P 皮弁と周囲の皮層を含めて行い， さらに上下顎骨の部分切除も行った. 腹直筋皮弁の挙 上は腫場切除と同時にスタートした. 皮弁作製時の切 開線をもとに皮䖉切開し筋皮弁を挙上させ腹直筋の内 面に皮成が生着しているのを確認しながら剥離を進め, 筋下面を縦走する下腹壁動静脈を明示し，同血管束を 外腸骨動脈との合流部付近まで剥離し皮弁を遊離させ た（写真 $3 \mathrm{~b})$. 筋皮弁を煩部に適合させて仮縫を行っ た後，血管吻合を行った。動脈は上甲状腺動脈 $(2.5$ $\mathrm{mm})$ を recipient vessel とし下腹壁動脈 $(2.2 \mathrm{~mm})$ と端々吻合した。静脈は下腹壁静脈が 2 本 $(3.0,1.0$ $\mathrm{mm})$ 走行していたのでそれぞれ外钼静脈 $(3.5 \mathrm{~mm})$ と内頸静脈の分枝 $(2.0 \mathrm{~mm})$ と端々吻合した，口腔内， 頬部, 䜖部の縫合を行い, 手術を終了した。

皮弁は生着し術後18日目に脂肪減量術を施行した。 術後 1 年経過しているが再発もなく外来にて経過観察 中である（写真 4). また腹部は一次縫縮できハルニア の発症もなく経過良好である。 


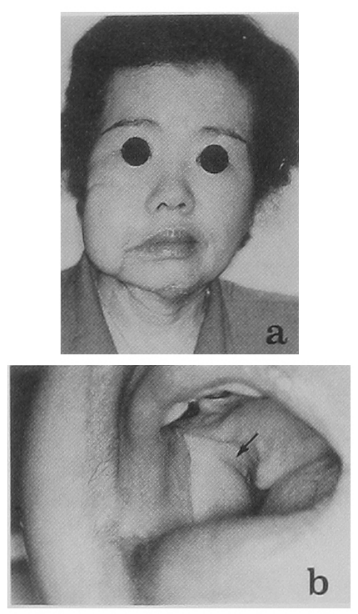

写真 4 術後写真（a: 顔貌, b: 口腔内） 写真は術後 8 か月目で矢印は筋皮弁に植皮した部分を示す

\section{考察}

再建手技の臨床経験の積み重ねより身体各部位で皮 弁や筋皮弁の挙上が可能となり，さらにマイクロサー ジェリーの進歩によってこれらの皮弁や筋皮弁を遠隔 部位に移植することが可能になった，回腔領域の軟組 織再建においても，局所皮弁や各種有茎皮弁に加えて 前腕皮弁，鼠径皮弁，腹直筋皮弁，肩甲皮弁や足背皮 弁などが使用されている2)。さらにこれらを組合わせ たりすることも可能である.このように再建手段は多 様化してきており術者は各症例ごとに最適の方法を選 択できる状況になりつつある.しかしながら各種再建 法にはおのずと制的があり，施行においては，それぞ れの特徴を把握した上で, 患者の全身状態や手術侵䘫 の程度, 手術時間, 体位変換の問題, マイクロサージェ リーの技術の習熟度などを考慮して慎重な選択が必要 である。

本症例のように煩部の全層欠損が大きくなると欠損 周囲の組織を翻転させて口腔内を閉鎖し, 類部皮膚を 皮弁で再建する方法は困難である。次に有茎皮弁で再 建することを考慮した場合，大胸筋皮弁や広背筋皮弁， D-P 皮弁，前額皮弁，広頸筋皮弁などが候補にあがる， 本症例は全頸部郭清を行っておらず, 茎部が頸部を通 る大胸筋皮弁や広背筋皮弁の使用は困難である。一次 治療時にD-P皮弁を使用しており，前額皮弁は患者 が女性で審美的な点で問題があり，広頸筋皮弁では欠 損が大き過ぎるため適㐫とならない。そこで再建法は 遊離皮弁が適応と考えられた，遊離皮弁を本症例に適 応する場合，(1)複数の皮弁を重ねあわせる。（2)皮弁を 折り畳む。 (3) 二島皮弁の作成が可能な肩甲皮弁を使用 する. (4)皮弁の内面に植皮をする.以上のいずれかを 選択する必要がある，本症例が再発例であり，手術手
技は可及的に単純であることが望ましいことより，皮 弁の重ねあわせは行わなかった. 皮弁を折り畳んだ場 合, 皮弁を $180^{\circ}$ 折り曲げなければならず bulkyな上, 折り䡒んだ皮弁の末梢が壊死に陥りやすくなる。また 肩甲皮弁は十分な大きさの皮弁を得ることができるが 皮弁挙上の際, 体位変換が必要である上に腫埕切除と 同時進行ができず，手術時間がかかる．皮弁の内面に 植皮をした遊離皮弁で再建する場合は腫場切除の前に 皮并作製術が必要で一期再建ができず，手術時期の遅 れが懸念される。しかし，今回は本症例が卮液腺腫場 であり、発育が緩慢であることから遊離皮弁の内面に 植皮を行う方法を採用した，そこで欠損の大きさから 考慮して腹直筋皮弁を選択した. 腹直筋皮弁は解剖学 的な変異がほとんどなく筋皮弁の挙上も簡単で栄養血 管である下腹壁動静脈は太く，長い血管茎が得られ， 血管吻合も容易であることが知られている4). 口腔癌 切除と筋皮弁挙上の同時手術が可能で体位変換の必要 もない. 皮弁採取部は一次縫縮が可能で植皮を必要と せず手術時間が短縮できる。また本筋皮弁は十分な組 織量を有しており患者の煩部の自然な膨隆感を形成す ることが可能であった。

このように植皮襄装した腹直筋皮弁による再建法は 腫㕫切除と再建手技とは別に皮弁への植皮処置が必要 となり，腫湯切除は植皮の生着まで数週間待たなけれ ばならない。したがって本法は発育緩慢な唾液腺腫塲 や良性腫湟切除後の即時再建や二次再建時に適応があ ると考えられる．また本法は㚘部の全層欠損だけでな く口蓋の広範囲欠損や口底と頸部両側の久損の再建に おいても適応可能であると考えられる。

\section{結語}

われわれは煩粘膜癌再発例 (61墄女性) に対し，植 皮裏装を行った腹直筋皮弁で再建を行い，良好な成績 を得たので報告した。

本論文の要旨については, 第 26 回日本口腔外科学会近 畿地方会 (1995 年 6 月奈良)において報告した.

\section{引用 文 献}

1）浜口裕弘，井上一男, 他 : 頭頸部癌の二次再建 時における局所皮并の活用. 日口外誌 37: 138513921991.

2）波利井清紀編：頭頸部外科最近の進歩。第一版, 克誠堂出版, 東京, 1993, 141-154 頁.

3）須郎 暢, 白砂兼光, 他 : 頪部小唾液腺に発生 した腺房細胞腫. 日口外誌 36: 385-388 1990.

4) Webster, M.H.C. and Soutar, D.S.: Practical Guide to Free Tissue Transfer. First Ed, Butterworths Co, England, 1986, p 6871. 